\title{
Increase of leishmanicidal and tubercular activities using steroids linked to aminoquinoline
}

\author{
Luciana MR Antinarelli $i^{1 \dagger}$, Arturene ML Carmo ${ }^{2 \dagger}$, Fernando R Pavan ${ }^{3}$, Clarice Queico F Leite ${ }^{3}$, Adilson D Da Silva ${ }^{2 *}$ \\ Elaine S Coimbra ${ }^{1}$ and Deepak B Salunke ${ }^{4}$
}

\begin{abstract}
Background: Aminoquinoline/steroid conjugates were synthesized based on the fact that steroid transporters have been shown to accept and carry a variety of drugs. So, in continuing our research of antileishmanial and antitubercular drugs, aminoquinoline/steroid conjugates $(12,13$, and 14$)$ were regioselectively synthesized via 1, 3-dipolar cycloaddition of alkynes 3, 5, and 7 with azide 12. The aminoquinoline/steroids conjugates were evaluated in vitro against Leishmania major and Mycobacterium tuberculosis.
\end{abstract}

Results: Regioselective synthesis of the novel aminoquinoline/steroid conjugates was achieved in very high yield. All aminoquinoline/steroid conjugates $(12,13$, and 14$)$ exhibited best results against Leishmania and $M$. tuberculosis than the respective alkyne intermediate structures (3, 5, and 7, respectively). Among them, the compound 12 exhibited the best activity for $\mathrm{M}$. tuberculosis $(\mathrm{MIC}=8.8 \mu \mathrm{M})$. This result is comparable to drugs commonly used in tuberculosis treatment. Also, for antileishmanial assay, the aminoquinoline/steroid conjugates demonstrated a significant activity against promastigote and amastigote forms of L. major.

Conclusions: Addition of a steroid group to aminoquinoline molecules enhanced the leishmanicidal and antitubercular activities. These results highlight the importance of steroids as carrier.

Keywords: Antileishmanial drugs, Antituberculosis drugs, Click chemistry, Quinoline, Steroid

\section{Background}

Quinolines are among the most important antimalarial drugs ever used [1,2]. In addition, quinoline derivatives have also demonstrated a variety of biological properties that includes antiviral, anti-inflammatory, antitubercular, and antileishmanial activities [2-5]. Leishmaniasis is a disease caused by parasitic protozoans of the genus Leishmania. Over 20 different Leishmania species can infect humans and cause a wide spectrum of symptoms. It has an estimated prevalence of 12 million cases worldwide, which is continuing to increase, with 1.5-2 million new cases each year [6]. With no available vaccine, the chemotherapy is a major control for the disease. However, the treatment options are severely limited and first line treatment is based on pentavalent antimonials that have been used in therapeutics for more than half a century [7]. Tuberculosis (TB)

\footnotetext{
* Correspondence: david.silva@ufjf.edu.br

${ }^{\dagger}$ Equal contributors

2Departamento de Química, I.C.E., Universidade Federal de Juiz de Fora,

Campus Universitário, Juiz de Fora, MG 36036-900, Brazil

Full list of author information is available at the end of the article
}

is another important neglected disease. TB is more prevalent in the world today than at any other time in human history. Mycobacterium tuberculosis (MTB), the pathogen responsible for $\mathrm{TB}$, uses diverse strategies to survive in a variety of host lesions and to evade immune surveillance $[7,8]$. The last 20 years have seen the worldwide appearance of multidrug-resistant $\mathrm{TB}$, followed by extensively drugresistant $\mathrm{TB}$, and most recently, strains that are resistant to all antituberculosis drugs [9]. Since the discovery of rifampicin (1960), no new drugs have been developed specifically against mycobacteria [10]. Also, only within the last few years some promising drug candidates have emerged [11]. Considering the inefficacy and the high toxicity of the currently used drugs for the treatment of these infectious diseases, as well as the emergence of drug-resistant strains of the causative organisms, the development of new leishmanicidal and antitubercular agents is extremely important.

Bioconjugation has emerged as a fast growing technology and aims at the ligation of two or more molecules to form new complexes with the combined properties of their individual components [12]. To make this linkage, 
the 1,2,3-triazole moieties are attractive as connecting units, since they are stable to metabolic degradation and capable of hydrogen bonding, which can be favorable in binding to biomolecular targets and also improves solubility [13]. Although the 1,2,3-triazole structural moiety does not occur in nature, the synthetic molecules containing the 1,2,3-triazole unit show diverse biological activities including antibacterial, herbicidal, fungicidal, anti-allergic, and anti-HIV [14]. Aminoquinoline/cholic acid conjugates were synthesized based on the fact that steroid transporters have been shown to accept and carry a variety of drugs [15]. Cholic acid is the most common form of the steroid and its derivatives are known to exhibit antimicrobial activities [16]. Bile acids are amphiphilic molecules which may represent alternatives for chemotherapeutic agents by acting synergistically with antibiotics as membrane permeabilizers [17-21]. Moreover, several bile acid/drug conjugates are shown to possess better activity than the precursor [22,23].

In a previous study, we demonstrate that 4-amino7-chloroquinoline derivatives showed an interesting antileishmanial and anti-MTB activities [24]. In continuation of this study were synthesized aminoquinoline conjugate with steroids in the expectation of improving its biological activity.

\section{Methods}

\section{General experimental techniques and apparatus}

TLC was performed on precoated silica gel F254 plates (0.25 mm; E. Merck). Infrared spectra were recorded on Schimadzu 8400 series FTIR instrument. ${ }^{1} \mathrm{H}$ NMR spectra were recorded on a Bruker AC-300 and 500 spectrometers at 300.13 and $500.13 \mathrm{MHz}$ and ${ }^{13} \mathrm{C}$ NMR spectra were recorded on a Bruker AC-300 at $75 \mathrm{MHz}$. The chemical shifts are given in parts per million relative to tetramethylsilane. Mass spectra were recorded on LCMS/MS-TOF API QSTAR PULSAR spectrometer, and samples were introduced by infusion method using Electro spray Ionization Technique. Standard work up: after extraction of all the reactions, the organic extracts were washed with water and brine and dried over anhydrous $\mathrm{Na}_{2} \mathrm{SO}_{4}$ and concentrated in vacuum.

\section{Synthesis of terminal acetylenes \\ General synthetic procedure for N-(7-chloroquinolin-4-yl) alkyl-diamine) $(2,4$, and 6$)$}

A mixture of 4,7-dichloroquinoline $(2.0 \mathrm{~g}, 10.1 \mathrm{mmol})$ and the corresponding diamines $(50.0 \mathrm{mmol})$, ethane1,2-diamine, propane-1,3-diamine, or buthane-1,4-diamine, was heated at $80^{\circ} \mathrm{C}$ for $1 \mathrm{~h}$ without stirring for $1 \mathrm{~h}$ and then at $110^{\circ} \mathrm{C}$ for $4-6 \mathrm{~h}$ with continued stirring to drive the reaction to completion. The reaction mixture was cooled to room temperature and diluted with dichloromethane. The organic layer was successively washed with $5 \% \mathrm{NaOH}(30 \mathrm{~mL})$ followed by water wash and then finally with brine. The organic layer was dried over anhydrous $\mathrm{Na}_{2} \mathrm{SO}_{4}$ and solvent was removed under reduced pressure to afford the compounds 2,4 , and $\mathbf{6}$, at $80-90 \%$ yield.

N-(7-chloroquinolin-4-yl)ethane-1,2-diamine (2) [25]:

Yellow solid, yield: $90 \% ; \mathrm{mp}=141^{\circ} \mathrm{C}\left(145-147^{\circ} \mathrm{C}\right)$.

N-(7-chloroquinolin-4-yl)propane-1,3-diamine (4) [25]:

Yellow solid, yield: $90 \%$; $\mathrm{mp}=97^{\circ} \mathrm{C}\left(96-98^{\circ} \mathrm{C}\right)$ [25].

$\mathrm{N}$-(7-chloroquinolin-4-yl)buthane-1,4-diamine (6) [25]:

Yellow solid, yield: $80 \%$; $\mathrm{mp}=123^{\circ} \mathrm{C}\left(122-124^{\circ} \mathrm{C}\right)$.

\section{General synthetic procedure for 7-chloro-N-(3-(prop-2-} ynylamino)alquil)quinolin-4-amine $(3,5$, and 7$)$

The compounds $2, \mathbf{4}$, and $\mathbf{6}(6.8 \mathrm{mmol})$ and propargyl bromide $(13.6 \mathrm{mmol})$, in presence of $\mathrm{K}_{2} \mathrm{CO}_{3}$ $(13.6 \mathrm{mmol})$, were dissolved in $\mathrm{EtOH}(5.0 \mathrm{~mL})$. The reaction mixture was stirred at $0^{\circ} \mathrm{C}$ for $2 \mathrm{~h}$ and then at $25^{\circ} \mathrm{C}$ for $48 \mathrm{~h}$. Solvent was removed in vacuum until dry. The crude reaction product was purified by flash chromatography (eluent: $\mathrm{MeOH} / \mathrm{CH}_{2} \mathrm{Cl}_{2}$ 5:95) producing the compounds 3,5 , and 7 , respectively $(2.5 \mathrm{mmol})$ in $60 \%$ yield as yellow solid.

\section{7-chloro-N-(2-(prop-2-ynylamino)ethyl)quinolin-4- amine (3) [24]: Yield: $60 \%, \mathrm{mp}=99^{\circ} \mathrm{C}$. \\ 7-chloro-N-(3-(prop-2-ynylamino)propyl)quinolin-4- amine (5) [24]: Yield: $60 \%, \mathrm{mp}=75^{\circ} \mathrm{C}$. \\ 7-chloro-N-(4-(prop-2-ynylamino)butyl)quinolin-4- amine (7) [24]: Yield: $62 \%, \mathrm{mp}=72^{\circ} \mathrm{C}$.}

\section{Synthesis of terminal azide}

\section{Synthesis of methyl 3a,7a,12a-trihydroxy-5 $\beta$-cholane-24-} oate (9)

Compound 9 was synthesized in overall good yield starting from bile acid 8 using the literature procedure [24]. White solid, m.p. $158^{\circ} \mathrm{C}$.

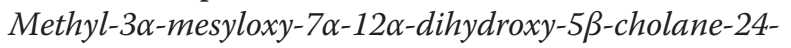
oate (10) [23]: To a solution of $9(2.0 \mathrm{~g}, 4.92 \mathrm{mmol})$ in $\mathrm{CH}_{2} \mathrm{Cl}_{2}(20 \mathrm{~mL})$ was added triethylamine $(6.4 \mathrm{~mL}$, $49.2 \mathrm{mmol})$ at $0^{\circ} \mathrm{C}$. Methane sulfonyl chloride $(0.5 \mathrm{~mL}$, $4.92 \mathrm{mmol}$ ) was added dropwise for $10 \mathrm{~min}$ at $0^{\circ} \mathrm{C}$. The reaction mixture was extracted with $\mathrm{CH}_{2} \mathrm{Cl}_{2} / \mathrm{H}_{2} \mathrm{O}$. Organic layer was washed with $\mathrm{NaHCO}_{3}$, water, and brine. The solvent was evaporated under reduced pressure. The crude product was purified by column chromatography (AcOEt/Hex 2:8) to obtain pure product 7 (1.9 g).

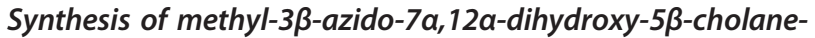
24-oate (11)

The compound $\mathbf{1 0}$ was reacted with $\mathrm{NaN}_{3}$ (5 equiv) in DMF for $24 \mathrm{~h}$ at $120^{\circ} \mathrm{C}$ to give product 11 [23]. White solid, m.p. $175^{\circ} \mathrm{C}$. 


\section{General procedure for cycloaddition (12-14)}

The alkyne 3, 5, or 7 ( 1 equiv) and the azide 11 (1.3 equiv) were dissolved in DMSO/ $\mathrm{H}_{2} \mathrm{O}$ 4:1 $(5 \mathrm{~mL})$. To this solution, $\mathrm{CuSO}_{4} .5 \mathrm{H}_{2} \mathrm{O}$ (0.05 equiv) and sodium ascorbate ( 0.40 equiv) were added. The reaction mixture was stirred for $48 \mathrm{~h}$ at room temperature and it was then extracted with $\mathrm{CH}_{2} \mathrm{Cl}_{2} / \mathrm{H}_{2} \mathrm{O}$. Organic layer was washed with $\mathrm{NaHCO}_{3}$, water, and brine. The solvent was evaporated under reduced pressure and crude product was purified by column chromatography on silica gel using $30 \% \mathrm{MeOH} / \mathrm{CH}_{2} \mathrm{Cl}_{2}$ system to obtain aminoquinoline/bile acid conjugates 12,13 , or 14, respectively, linked with 1,4-disubstituted 1,2,3-triazole in $60 \%$ yield.

Methyl 3 $3-(N-[(7-c h l o r o q u i n o l i n-4-y l) a m i n o] e t h y l a m i-$ nomethyl)-1 H-1,2,3-triazol-1-yl)]7 $\alpha$-12 $\alpha$-dihydroxy-5 $\beta$-cholane-24-oate (12): Yellow crystalline solid; m.p. $128^{\circ} \mathrm{C}$, $\mathrm{v}_{\max }(\mathrm{KBr})$ : $3340(\mathrm{NH}), 2930(\mathrm{CH}) ;{ }^{1} \mathrm{H}$ NMR $(300 \mathrm{MHz}$, $\left.\mathrm{CD}_{3} \mathrm{OD}\right): 8.31$ (d, $\left.1 \mathrm{H}, J_{2,3}=4 \mathrm{~Hz}, \mathrm{H}-2^{\prime}\right) ; 8.08(\mathrm{~d}, 1 \mathrm{H}$, $\left.J_{5,6}=6 \mathrm{~Hz}, \mathrm{H}-5^{\prime}\right) ; 7.88(\mathrm{~s}, 1 \mathrm{H}, \mathrm{H}-4$ " triazole); $7.73(\mathrm{~s}$, $1 \mathrm{H}, \mathrm{H}-8^{\prime}$ ); 7.37 (dd, $1 \mathrm{H}, J_{6,5}=6 \mathrm{~Hz}, J=2 \mathrm{~Hz}, \mathrm{H}-6^{\prime}$ ); 6.51 (d, $\left.1 \mathrm{H}, J_{3,2}=4 \mathrm{~Hz}, \mathrm{H}-3^{\prime}\right) ; 4.53$ (s, $\left.1 \mathrm{H}, \mathrm{H}-12\right) ; 3.60$ (s, $1 \mathrm{H}, \mathrm{H}-7$ ); 3.89 (s, $2 \mathrm{H}, \mathrm{H}-3$ "); 3.49 (s, $3 \mathrm{H}, \mathrm{H}-25$ ); 3.45 (m, $2 \mathrm{H}, \mathrm{H}-1$ ) ; 2.93 (m, $2 \mathrm{H}, \mathrm{H}-2$ "); 0.97 (d, $3 \mathrm{H}$, $J=6 \mathrm{~Hz}, \mathrm{H}-21)$; 0.76 (s, $3 \mathrm{H}, \mathrm{H}-18)$; 0.65 (s, $3 \mathrm{H}, \mathrm{H}-19$ ); ${ }^{13} \mathrm{C}$ NMR (75 MHz, CD $\left.\mathrm{OD}\right): 176.4(\mathrm{C}-24) ; 152,6$ (C-4'); 152.0 (C-2'); 149.3 (C-9'); 146.3 (C-3" triazole); 136.3 (C7'); 127.3 (C-8'); 125.9 (C-6'); 124.3 (C-4" triazole); 123.3 (C-5'); 118.6 (C-10'); 99.5 (C-3'); 73.7 (C-12); 68.7 (C-7); 58.2 (C-3); 51.8 (C-13); 48.8 (C-25); 47.1 (C-2); 23.3 (C21); 17.4 (C-19); $12.8(\mathrm{C}-18)$; HRMS ESI $[\mathrm{M}+\mathrm{H}]^{+}: \mathrm{m} / \mathrm{z}$ : Calc for $\mathrm{C}_{39} \mathrm{H}_{56} \mathrm{~N}_{6} \mathrm{O}_{4} \mathrm{Cl} 707.4052[\mathrm{M}+\mathrm{H}]^{+}$, found $707.4059[\mathrm{M}+\mathrm{H}]^{+}$.

Methyl 33-(N-[(7-chloroquinolin-4-yl)amino]propylaminomethyl)-1 H-1,2,3-triazol-1-yl)]7 $\alpha$-12 $\alpha$-dihydroxy5 $\beta$-cholane-24-oate (13): Yellow oil; $v_{\max }(\mathrm{KBr}): 3345$ (NH), $2928(\mathrm{CH}) ;{ }^{1} \mathrm{H}$ NMR (300 MHz, $\left.\mathrm{CDCl}_{3}\right): 8.38$ (d, $\left.1 \mathrm{H}, J_{2,3}=4 \mathrm{~Hz}, \mathrm{H}-2^{\prime}\right) ; 7.87$ (s, $\left.1 \mathrm{H}, \mathrm{H}-8^{\prime}\right) ; 7.74(\mathrm{~d}, 1 \mathrm{H}$, $\left.J_{5,6}=6 \mathrm{~Hz}, \mathrm{H}-5^{\prime}\right) ; 7.52(\mathrm{~s}, 1 \mathrm{H}, \mathrm{H}-5$ " triazole); $7.20(\mathrm{dd}$, $\left.1 \mathrm{H}, J_{6,5}=6 \mathrm{~Hz}, J=2 \mathrm{~Hz}, \mathrm{H}-6^{\prime}\right) ; 6.27\left(\mathrm{~d}, 1 \mathrm{H}, J_{3,2}=4 \mathrm{~Hz}\right.$, H-3'); 4.53 (s, 2 H, H-4"); 3.87 (s, 1 H, H-7); 3.65 (s, 3 H, H-25); 3.45 (m, 2 H, H-1"); 0.97 (d, $3 \mathrm{H}, J=6 \mathrm{~Hz}, \mathrm{H}-21$ ); 0.81 (s, $3 \mathrm{H}, \mathrm{H}-18) ; 0.68$ (s, $3 \mathrm{H}, \mathrm{H}-19) ;{ }^{13} \mathrm{C} \mathrm{NMR}$ (75 MHz, $\left.\mathrm{CDCl}_{3}\right): 174.9$ (C-24); 151.4 (C-4'); 150.2 (C2'); 144.6 (C-9'); 144.6 (C-4" triazole); 135.5 (C-7'); 126.8 (C-8'); 125.4 (C-6'); 123.0 (C-5" triazole); 122.9 (C-5'); 121.4 (C-10'), 114.0 (C-3'), 73.0 (C-12), 68.2 (C-7), 57.0 (C-3), 51.7 (C-13), 48.4 (C-25), 47.4 (C-2), 38.3 (C-14); 22.9 (C-21); 17.5 (C-19); 12.7 (C-18); HRMS ESI $[\mathrm{M}+\mathrm{H}]^{+}$: $\mathrm{m} / \mathrm{z}$ : Calc for $\mathrm{C}_{40} \mathrm{H}_{58} \mathrm{~N}_{6} \mathrm{O}_{4} \mathrm{Cl} 721.4108[\mathrm{M}+\mathrm{H}]^{+}$, found $721.4210[\mathrm{M}+\mathrm{H}]^{+}$.

Methyl 3ß-(N-[(7-chloroquinolin-4-yl)amino]buthylaminomethyl)-1 $\quad H$-1,2,3-triazol-1-yl)]7 $\alpha$-12 $\alpha$-dihydroxy$5 \beta$-cholane-24-oate (14).
Yellow oil; $v_{\max }(\mathrm{KBr}): 3347(\mathrm{NH}), 2931(\mathrm{CH}) ;{ }^{1} \mathrm{H}$ $\operatorname{NMR}\left(300 \mathrm{MHz}, \mathrm{CDCl}_{3}\right): 8.44$ (d, $1 \mathrm{H}, J_{2,3}=2 \mathrm{~Hz}, \mathrm{H}-2$ '); 7.88 (s, $1 \mathrm{H}, \mathrm{H}-8^{\prime}$ ); 7.77 (d, $\left.1 \mathrm{H}, J_{5,6}=6 \mathrm{~Hz}, \mathrm{H}-5^{\prime}\right) ; 7.51$ (s, $1 \mathrm{H}, \mathrm{H}-7$ " triazol); $7.23\left(\mathrm{dd}, 1 \mathrm{H}, J_{6,5}=6 \mathrm{~Hz}, J=2 \mathrm{~Hz}\right.$, H-6'); 6.32 (d, 1 H, $\left.J_{3,2}=2 \mathrm{~Hz}, \mathrm{H}-3^{\prime}\right) ; 3.92$ (s, $2 \mathrm{H}, \mathrm{H}-4^{\prime \prime}$ ); 3.88 (s, 1 H, H-7); 3.66 (s, 3 H, H-25); 3.28 (m, 2 H, H1"); 0.99 (d, $3 \mathrm{H}, J=6 \mathrm{~Hz}, \mathrm{H}-21)$; 0.82 (s, $3 \mathrm{H}, \mathrm{H}-18)$; 0.68 (s, $3 \mathrm{H}, \mathrm{H}-19) ;{ }^{13} \mathrm{C}$ NMR $\left(75 \mathrm{MHz}, \mathrm{CDCl}_{3}\right): 174.9$ (C-24); 151.6 (C-4'); 150.5 (C-2'); 148.7 (C-9'); 145.3 (C6" triazole); 134.8 (C-7'); 127.8 (C-8'); 124.9 (C-6'); 122.3 (C-7" triazole); $121.2\left(\mathrm{C}-5^{\prime}\right) ; 117.4\left(\mathrm{C}-10^{\prime}\right) ; 98.8\left(\mathrm{C}-3^{\prime}\right)$; 72.9 .0 (C-12); 68.0 (C-7); 56.9 (C-3); 51.6 (C-13); 48.7 (C-25); 47.3 (C-2); 22.9 (C-21); 17.5 (C-19); 12.7 (C-18); HRMS ESI $[\mathrm{M}+\mathrm{H}]^{+}: \mathrm{m} / \mathrm{z}$ : Calc for $\mathrm{C}_{41} \mathrm{H}_{60} \mathrm{~N}_{6} \mathrm{O}_{4} \mathrm{Cl}$ $735.4365[\mathrm{M}+\mathrm{H}]^{+}$, found $735.4362[\mathrm{M}+\mathrm{H}]^{+}$.

\section{Biological evaluation Anti-MTB activity}

The anti-MTB activity of the compounds was determined by the Resazurin Microtiter Assay (REMA) [26]. Stock solutions of the test compounds were prepared in dimethyl sulfoxide (DMSO) and diluted in Middlebrook 7 H9 broth (Difco), supplemented with oleic acid, albumin, dextrose and catalase (OADC enrichment-BBL/ Becton Dickinson, Sparks, MD, USA), to obtain final drug concentration ranges from 0.15 to $250 \mu \mathrm{M}$. The serial dilutions were realized in a Precision XS Microplate Sample Processor $\left(\right.$ Biotek $\left.^{\mathrm{TM}}\right)$. The isoniazid was dissolved in distilled water, as recommended by the manufacturer (Difco laboratories, Detroit, MI, USA), and used as a standard drug. MTB $\mathrm{H}_{37} \mathrm{Rv}$ ATCC 27294 was grown for 7 to 10 days in Middlebrook 7 H9 broth supplemented with OADC, plus $0.05 \%$ Tween 80 to avoid clumps. Cultures were centrifuged for $15 \mathrm{~min}$ at $3,150 \mathrm{~g}$, washed twice, and resuspended in phosphatebuffered saline and aliquots were frozen at $-80^{\circ} \mathrm{C}$. After 2 days, an aliquot was thawed to determine the viability and the CFU after freezing. MTB $\mathrm{H}_{37} \mathrm{Rv}$ (ATCC 27294) was thawed and added to the test compounds, yielding a final testing volume of $200 \mu \mathrm{L}$ with $2 \times 10^{4} \mathrm{CFU} / \mathrm{mL}$. Microplates with serial dilutions of each compound were incubated for 7 days at $37^{\circ} \mathrm{C}$, after resazurin was added to test viability. Wells that turned from blue to pink, with the development of fluorescence, indicated growth of bacterial cells, while maintenance of the blue color indicated bacterial inhibition [26]. The fluorescence was read $(530 \mathrm{~nm}$ excitation filter and $590 \mathrm{~nm}$ emission filter) in a SPECTRAfluor Plus $\left(\right.$ Tecan $\left.^{\circledR}\right)$ microfluorimeter. The MIC was defined as the lowest concentration resulting in $90 \%$ inhibition of growth of MTB. As a standard test, the MIC of isoniazid was determined on each microplate. The acceptable range of isoniazid MIC is from 0.11 to $0.44 \mu \mathrm{M}[10,33]$. Each test was set up in triplicate. 
<smiles>Clc1ccc2c(Cl)ccnc2c1</smiles>

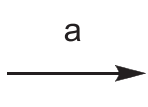<smiles>Cc1ccc(Cl)cc1NC[Al]N</smiles><smiles>C#CCNCCNc1ccnc2cc(Cl)ccc12</smiles>

Figure 1 Reagents and conditions: (a) ethane-1,2-diamine, propane-1,3-diamine, or butane-1,4-diamine, $80^{\circ} \mathrm{C}$ for $1 \mathrm{~h}, 110^{\circ} \mathrm{C}$ for $4 \mathrm{~h}$, $90 \%$; (b) propargyl bromide, $\mathrm{K}_{2} \mathrm{CO}_{3}, \mathrm{EtOH}, 25^{\circ} \mathrm{C}, 48 \mathrm{~h}, 60 \%$.

\section{In vitro antileishmanial activity}

\section{Parasites and cell culture}

Promastigote forms of L. major (MRHO/SU/59/P) were maintained in Medium BHI supplemented with $10 \%$ fetal bovine serum (FBS) at $24^{\circ} \mathrm{C}$. FBS was purchased from Cultilab (Campinas, São Paulo, Brazil) and brain heart infusion (BHI) from Himédia (Mumbai, India).

\section{Promastigote forms}

The viability of parasites was determined by the colorimetric 3-(4,5-dimethylthiazol-2-yl)-2,5-diphenyl-tetrazolium bromide (purchased by Sigma Chemical Co., St. Louis, MO, USA) or MTT method, based on tetrazolium salt reduction by mitochondrial dehydrogenases [27]. Briefly, promastigotes of L. major from a logarithmic phase culture were suspended to yield 2 million cells/ $\mathrm{mL}$ after Neubauer chamber counting. The screening was performed in 96-well microtiter plates maintained at $24^{\circ} \mathrm{C}$. Controls with DMSO and without drugs were performed. Absorbance was measured at $570 \mathrm{~nm}$ (Multiskan MS microplate reader, LabSystems Oy, Helsink,
Finland). The results are expressed as the concentrations inhibiting parasite growth by $50 \%\left(\mathrm{IC}_{50}\right)$ after a 3-day incubation period. Amphotericin B (supplied by Cristália, São Paulo, Brazil) was used as the reference standard. For data analysis: $\mathrm{IC}_{50}$ values were carried out at $5 \%$ significance level ( $p<0.05$, CI 95\%), calculated using a nonlinear regression curve, by using GraFit Version 5 software (Erithacus Software Ltd., Horley, UK).

\section{Amastigote forms}

Concerning the amastigotes in vitro model, inflammatory macrophages were obtained from BALB/c mice previously inoculated with $3 \%$ thioglycollate medium (Sigma Chemical Co.). Briefly, peritoneal macrophages were plated at $2 \times 10^{6}$ cells $/ \mathrm{mL}$ on coverslips (13-mm diameter) previously arranged in a 24-well plate in RPMI 1640 medium supplemented with $10 \%$ inactivated FBS, and allowed to adhere for $24 \mathrm{~h}$ at $37^{\circ} \mathrm{C}$ in $5 \% \mathrm{CO}_{2}$. Adherent macrophages were infected with $L$. major (MRHO/SU/59/P) promastigotes in the stationary growth phase using a ratio of $1: 10$ at $37^{\circ} \mathrm{C}$ for $3 \mathrm{~h}$. Non-internalized promastigotes were eliminated and<smiles>CC(C)CCC(=O)O</smiles>

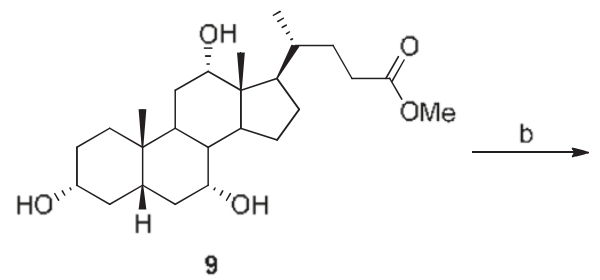<smiles>COC(=O)CC[C@H](C)[C@H]1CCC2C3C(C[C@H](O)[C@]21C)[C@@]1(C)CC[C@@H](OC)C[C@H]1C[C@H]3O</smiles><smiles>COC(=O)CC[C@@H](C)[C@H]1CCC2C3C(C[C@H](O)[C@]21C)[C@@]1(C)CC[C@@H](N)C[C@H]1[C@H]3O</smiles>

Figure 2 Reagents and conditions: (a) $\mathrm{HCl} / \mathrm{MeOH}, 25^{\circ} \mathrm{C}, 24 \mathrm{~h}, 98 \%$; (b) $\mathrm{MsCl}^{\mathrm{Et}} \mathrm{Et}_{3} \mathrm{~N}, \mathrm{CH}_{2} \mathrm{Cl}_{2}, 0^{\circ} \mathrm{C}, 2 \mathrm{~h}, 80 \%$; (c) $\mathrm{NaN}{ }_{3}, \mathrm{DMF}^{2}, 120^{\circ} \mathrm{C}, 24 \mathrm{~h}$, $70 \%$. 
solutions of tested compounds were added and maintained at $37^{\circ} \mathrm{C}$ in $5 \% \mathrm{CO}_{2}$ for $72 \mathrm{~h}$. Slides were fixed and stained with Giemsa for parasite counting (optical microscopy, $1000 \times$ magnification). Amphotericin B was used as a standard drug and the reduction of the number of amastigotes was evaluated after only 24 -h post-infection $(0.1 \mu \mathrm{M}=35 \%$ and $1.0 \mu \mathrm{M}=48 \%$ of reduction of intracellular amastigotes). The data were analyzed using GraphPad Prism 5.0 (GraphPad Software, San Diego, CA, USA), which considered the mean of two assays performed in duplicate. One-way ANOVA was applied to compare all the groups. Differences were regarded as significant when $p<0.0001\left(^{(* * *)}\right.$ ) and $p<0.001(* *)$.

\section{Results and discussion Chemistry}

The aminoquinoline/steroids conjugates 12, 13, and 14 were synthesized via 1,3-dipolar cycloaddition of alkyne 3, 5, or 7, respectively, with an azide group of the bile acid 11. 4,7-dichloroquinoline 1 on treatment with ethylenediamine, propanediamine, or butanediamine at $80-110^{\circ} \mathrm{C}$ for $4 \mathrm{~h}$ furnished the intermediates $\mathrm{N}$-(2-aminoethyl)-7-chloroquinolin-4-amine (2), $\mathrm{N}$-(3aminopropyl)-7-chloroquinolin-4-amine (4), and $N$-(4aminobutyl)-7-chloroquinolin-4-amine (6) in $90 \%$ yield [25]. These intermediates $\mathbf{2}, \mathbf{4}$, or $\mathbf{6}$ on further
Table 1 Effect of the compounds on promastigote forms of $L$. major, murine peritoneal macrophages and $M$. tuberculosis

\begin{tabular}{|c|c|c|}
\hline \multirow[t]{2}{*}{ Compounds } & \multicolumn{2}{|l|}{ Biological tests $(\mu \mathrm{M})$} \\
\hline & M. tuberculosis (MIC) ${ }^{\mathrm{a}}$ & L. major $\left(I C_{50}\right)^{b}$ \\
\hline 3 & $60.1^{c}$ & $20.6^{C}$ \\
\hline 5 & $60.1^{c}$ & $45.0^{c}$ \\
\hline 7 & $54.2^{c}$ & $>87.0^{c}$ \\
\hline 12 & 8.8 & 10.6 \\
\hline 13 & 17.3 & 21.2 \\
\hline 14 & 17.0 & 25.6 \\
\hline$A m B^{*}$ & - & 0.3 \\
\hline Isoniazid* & $0.11-0.44$ & - \\
\hline
\end{tabular}

Values represent the mean of triplicate samples.*AmB (amphotericin B) and isoniazid were used as reference drug for antileishmanial and anti-MTB assays, respectively. ${ }^{\mathrm{a}} \mathrm{I} \mathrm{C}_{50}$ values (concentrations inhibiting parasite growth by $50 \%$ ). ${ }^{b} \mathrm{MIC}$ : lowest concentration resulting in $90 \%$ inhibition of growth of MTB. 'Data have been reported previously [24].

treatment with propargyl bromide and $\mathrm{K}_{2} \mathrm{CO}_{3}$ in $\mathrm{EtOH}$ at $25^{\circ} \mathrm{C}$ for $48 \mathrm{~h}$ yielded compounds $\mathbf{3}, \mathbf{5}$, and 7 , respectively, in 60\% yield (see Figure 1) [28].

The C-3-azido steroid (bile acid) derivative $\mathbf{1 1}$ was synthesized according to the literature procedures $[29,30]$ with small modifications (see Figure 2). Finally, the

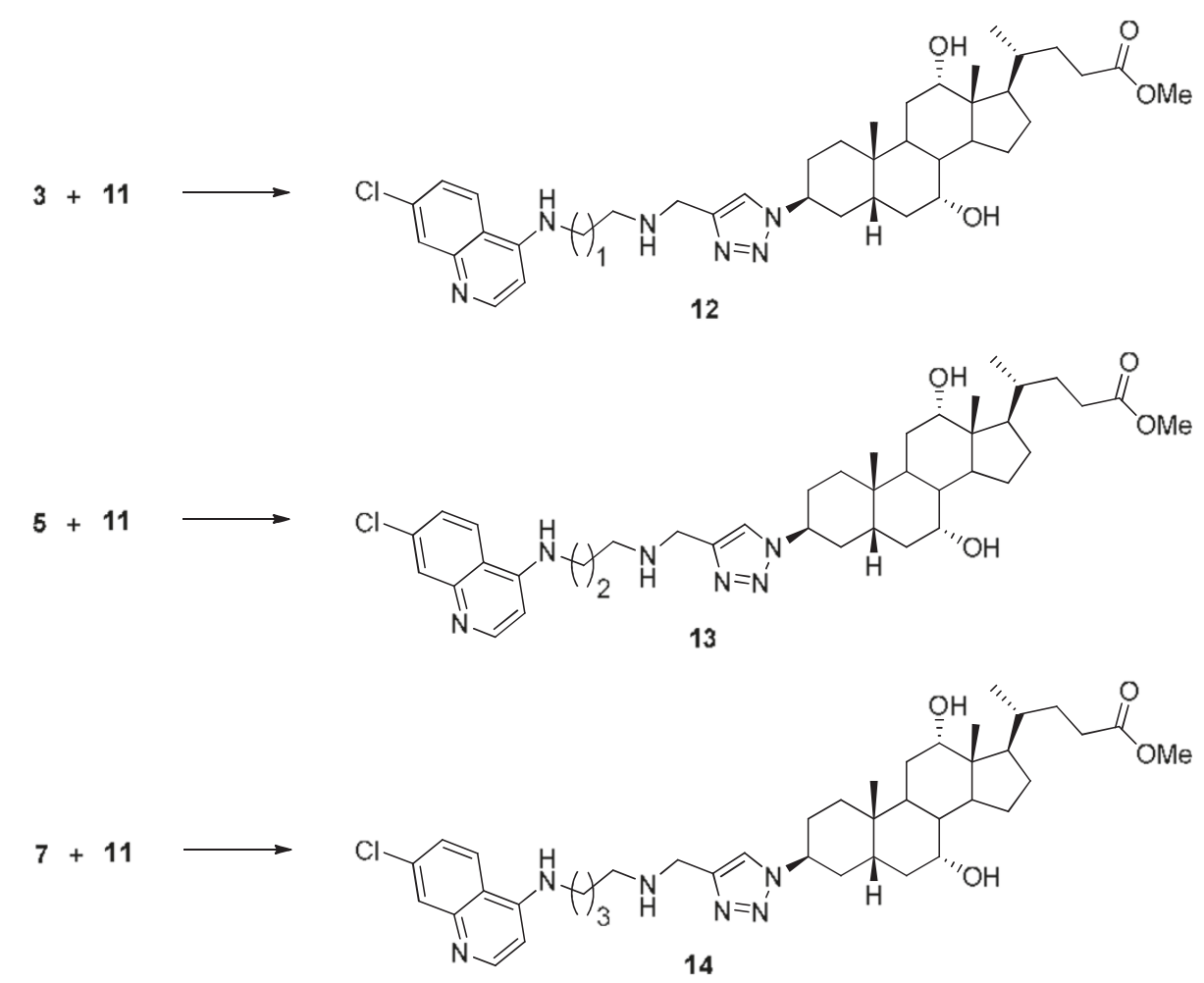

Figure 3 Reagents and conditions: (a) $\mathrm{CuSO}_{4} \cdot 5 \mathrm{H}_{2} \mathrm{O}$, sodium ascorbate, DMSO/ $\mathrm{H}_{2} \mathrm{O}(1: 1), 25^{\circ} \mathrm{C}, 96 \mathrm{~h}, 60 \%$. 
aminoquinoline/steroid (bile acid) conjugates 12, 13, and 14 were synthesized in very high yield via 1,3-dipolar cycloaddition of alkyne 3, 5, or 7 with an azide group of the bile acid 11, respectively, using $\mathrm{CuSO}_{4} \cdot 5 \mathrm{H}_{2} \mathrm{O}$, sodium ascorbate, $\mathrm{DMSO} / \mathrm{H}_{2} \mathrm{O}(1: 1)$ at $25^{\circ} \mathrm{C}$ for $96 \mathrm{~h}$, in $60 \%$ yield (see Figure 3). All the compounds were well characterized by ${ }^{1} \mathrm{H}$ NMR, ${ }^{13} \mathrm{C}$ NMR, and HRMS.

\section{Biological evaluation}

Previous study demonstrated that 4-amino-7-chloroquinoline derivatives (2-7) showed an interesting antileishmanial and anti-MTB activities [24]. In continuation of this study, novel steroid linked aminoquinolines were synthesized in an anticipation to improve its biological activity. Table 1 shows the biological results comparing
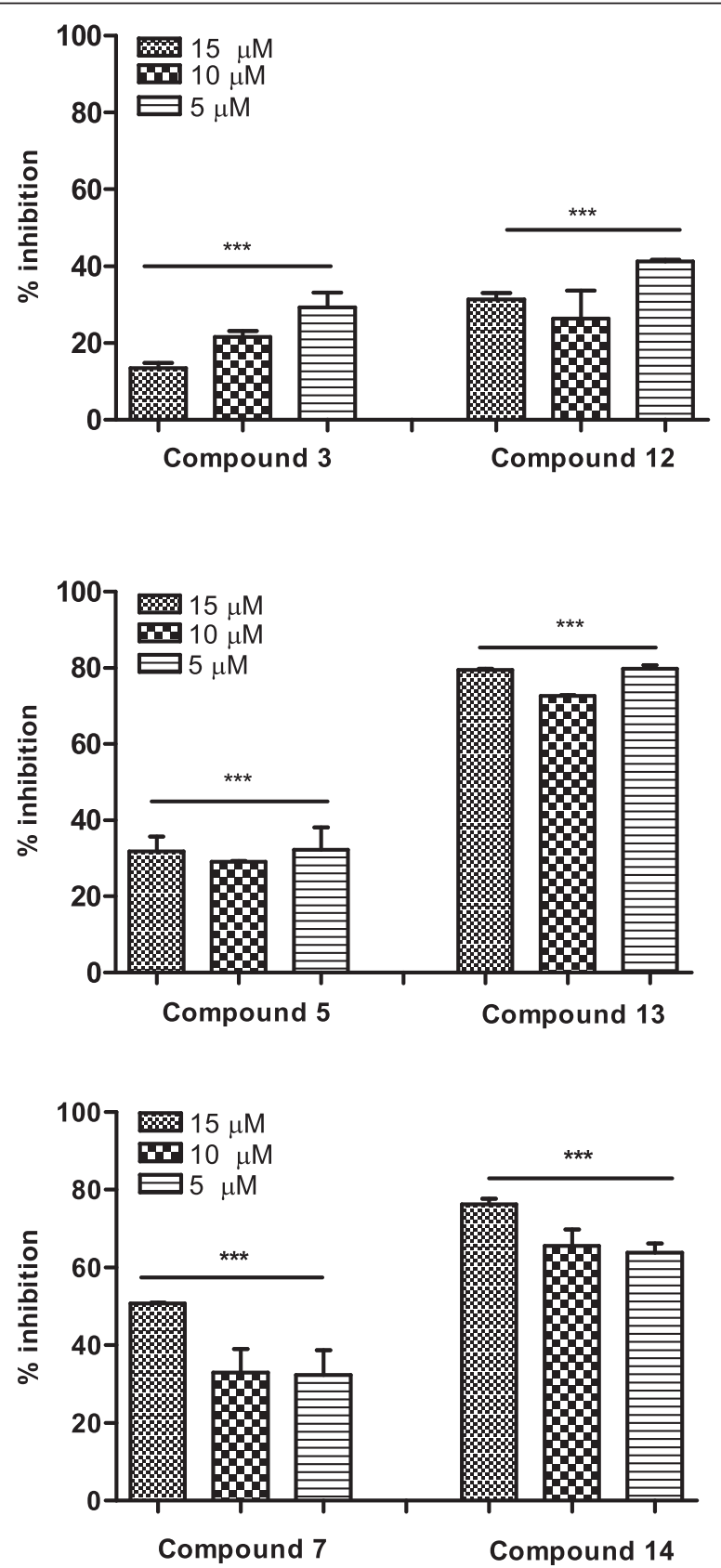

Figure 4 Effect of alkyne intermediate structures $(3,5$ and 7$)$ and aminoquinoline/steroid conjugates (12, 13 and 14) on intracellular amastigotes. Peritoneal macrophages previously infected with L. major promastigotes in the stationary growth phase were exposed to the compounds for $72 \mathrm{~h}$. Results from two assays in duplicate are shown as percentage of growth inhibition in relation to untreated control. All results were significant $(* * * 0.0001)$. 
the alkyne intermediate structures $(3,5$, and 7$)$ and their corresponding aminoquinoline/steroid conjugate products $(12,13$, and 14).

Anti-MTB activity of the compounds increased in the following order: alkyne intermediate structures $(\mathbf{3}, \mathbf{5}$, and 7)< aminoquinoline/steroid conjugates (12-14). The aminoquinoline/steroid conjugates (12-14) showed excellent results with MICs ranging from 8.8 to $17.3 \mu \mathrm{M}$. Within these conjugates, the compound 12 was the most active against MTB bacilli $(8.8 \mu \mathrm{M})$ and the presence of the shortest ethylenodiamine linker was enough to demonstrate the improved activity. The minimum inhibitory concentration (MIC) value found for the compound $\mathbf{1 2}$ is comparable or better than the MIC of some "second-line" drugs currently used in TB therapy such as cycloserine (122.4-489.7 $\mu \mathrm{M})$, kanamycin (2.1-8.6 $\mu \mathrm{M})$, tobramycin $(8.6-17.1 \mu \mathrm{M})$, and clarithromycin $(10.7-21.4 \mu \mathrm{M})$ [31].

For antileishmanial test, the assay was performed in both promastigote and amastigote forms of Leishmania since both stages of parasite are used for drug screening research [32-34]. Table 1 shows $\mathrm{IC}_{50}$ values of synthesized compounds on promastigote forms of L. major. Aminoquinoline/steroid conjugates (12-14) were more active than the respective alkyne intermediate structures $(3,5$, and 7 , respectively). Among them, the compound 12 was the most active in promastigotes of $L$. major, inhibiting two times more the viability of the parasite than the alkyne intermediate 3.

Although the promastigotes of the Leishmania genus are used for screening of compounds, this assay must be considered as preliminary because: this stage of parasite is significantly more susceptible to drug-induced effects than amastigote, the amastigote are responsible for all clinical manifestations in humans and the intracellular amastigote model has been cited as the golden standard for in vitro Leishmania drug discovery research [33,34]. L. majormacrophage treated with the aminoquinoline/steroid compounds (12-14) showed a significant inhibitory effect against the intracellular amastigotes, as evidenced in Figure 4. Addition of a steroid group to aminoquinoline molecules again enhanced the biological activity of the compounds. Results showed that the compounds 13 and 14 showed the best antiproliferative effects on intracellular amastigotes, inhibiting between 64 and $80 \%$ of the parasite burden. These assays were performed in concentrations above those toxic for murine macrophages.

Antileishmanial and anti-MTB results confirm the importance of steroid groups such cholic acid acting as carriers. The cholic acid-derived carriers can possibly increase the solubility in physiological conditions and it could lead to increased cell permeability due to the amphiphilic character of the molecule and could function as an ionophore [22]. Further in vivo mouse model studies could better elucidate the role of bile acid derivatives as carriers.

\section{Conclusions}

Regioselective synthesis of the novel aminoquinoline/ steroid conjugates was achieved in very high yield. Addition of a steroid group to aminoquinoline molecules enhanced the anti-MTB activity, having lower MICs than some drugs commonly used to treat TB. For antileishmanial assay, the aminoquinoline/steroid conjugates demonstrated a significant activity against promastigote and amastigote forms of L. major.

\section{Abbreviations}

BHI: Brain heart infusion; FBS: Fetal bovine serum; $\mathrm{IC}_{50}$ : Concentrations inhibiting parasite growth by 50\%; MIC: Minimum inhibitory concentration; MTB: Mycobacterium tuberculosis; TB: Tuberculosis.

\section{Competing interests}

The authors declare that they have no competing interests.

\section{Acknowledgments}

This study was supported by the FAPEMIG, FAPESP, CAPES, CNPq and BIC/ UFJF.

\section{Author details}

${ }^{1}$ Departamento de Parasitologia, Microbiologia e Imunologia, I.C.B Universidade Federal de Juiz de Fora, Campus Universitário, Juiz de Fora, MG 36036-900, Brazil. Departamento de Química, I.C.E., Universidade Federal de Juiz de Fora, Campus Universitário, Juiz de Fora, MG 36036-900, Brazil. ${ }^{3}$ Departamento de Ciências Biológicas, F.C. F., Universidade Estadual Paulista "Júlio de Mesquita Filho", Rod. Araraquara-Jaú Km.01 s/n, Campus, 14801-902, Araraquara, SP, Brazil. ${ }^{4}$ Centre National de la Recherche Scientifique, Institut de Chimie des Substances Naturelles, UPR 2301 CNRS, Avenue de la Terrasse, 91198, Gif-sur-Yvette, France.

Received: 16 September 2011 Accepted: 15 January 2012

Published: 2 May 2012

\section{References}

1. Kaur K, Jain M, Reddy RP, Jain R: Quinolines and structurally related heterocycles as antimalarials. Eur J Med Chem 2010, 45:3245.

2. Kaur K, Jain M, Khan SI, Jacob MR, Tekwani BL, Singh S, Singh PP, Jain R: Synthesis, antiprotozoal, antimicrobial, $\beta$-hematin inhibition, cytotoxicity and methemoglobin (MetHb) formation activities of bis(8aminoquinolines). Bioorg Med Chem 2011, 19:197.

3. Vieira NC, Herrenknecht C, Vacus J, Fournet A, Bories C, Figadère B, Espindola LS, Loiseau PM: Selection of the most promising 2-substituted quinoline as antileishmanial candidate for clinical trials. Biomed Pharmacother 2008, 62:684.

4. Tekwani BL, Walker LA: 8-Aminoquinolines: future role as antiprotozoal drugs. Curr Opin Infect Dis 2006, 19:623.

5. Kaur K, Patel SR, Patil P, Jain M, Khan SI, Jacob MR, Ganesan S, Tekwani BL, Jain R: Synthesis, antimalarial, antileishmanial, antimicrobial, cytotoxicity, and methemoglobin (MetHB) formation activities of new 8-quinolinamines. Bioorg Med Chem 2007, 15:915.

6. World Health Organization: Leishmaniasis; http://www.who.int/leishmaniasis/ en/. Accessed May 16, 2011

7. Baiocco P, Colotti G, Franceschini S, Ilari A: Molecular basis of antimony treatment in leishmaniasis. J Med Chem 2009, 23:2603.

8. Koul A, Arnoult E, Lounis N, Guillemont J, Andries K: The challenge of new drug discovery for tuberculosis. Nature 2011, 469:483.

9. Gandhi NR, Nunn P, Dheda K, Schaaf HS, Zignol M, van Soolingen D, Jensen $P$, Bayona J: Multidrug-resistant and extensively drug-resistant tuberculosis: a threat to global control of tuberculosis. Lancet 2010, 22:1830. 
10. Pavan FR, Poelhsitz GV, Do Nascimento FB, Leite SR, Batista AA, Deflon VM, Sato DN, Franzblau SG, Leite CQ: Ruthenium (II) phosphine/picolinate complexes as antimycobacterial agents. Eur J Med Chem 2010, 45:598.

11. Barry CE 3rd, Slayden RA, Sampson AE, Lee RE: Use of genomics and combinatorial chemistry in the development of new antimycobacterial drugs. Biochem Pharmacol 2000, 59:221.

12. Hermanson GT: Bioconjugate techniques. San Diego: Academic; 1996.

13. Breinbauer $\mathrm{R}$, Kohn M: Azide-alkyne coupling: a powerful reaction for bioconjugate chemistry. Chembiochem 2003, 4:1147.

14. Kharb R, Sharma PC, Yar MS: Pharmacological significance of triazole scaffold. J Enz Inhib Med Chem 2011, 26:1.

15. Bhat $L$, Jandeleit B, Dias TM, Moors TL, Gallop MA: Synthesis and biological evaluation of novel steroidal pyrazoles as substrates for bile acid transporters. Bioorg Med Chem Lett 2005, 15:85.

16. Savage PB, Li C: Cholic acid derivatives: novel antimicrobials. Exp Opin Investig Drugs 2000, 9:263.

17. Bavikar SN, Salunke DB, Hazra BG, Pore VS, Dodd RH, Thierry J, Shirazi F, Deshpande MV, Kadreppa S, Chattopadhyay S: Synthesis of chimeric tetrapeptide-linked cholic acid derivatives: impending synergistic agents. Bioorg Med Chem Lett 2008, 18:5512.

18. Pore VS, Aher NG, Kumar M, Shukla PK: Design and synthesis of fluconazole/bile acid conjugate using click reaction. Tetrahedron 2006, 62:11178.

19. Enhsen A, Kramer W, Wess G: Bile acids in drug discovery. Drug Discov Today 1998, 3:409.

20. Kannan A, De Clercq E, Pannecouque C, Witvrouw M, Hartman TL, Turpin JA, Buckheit RW Jr, Cushman M: Synthesis and anti-HIV activity of a bile acid analog of cosalane. Tetrahedron 2001, 57:9385.

21. Anelli PL, Lattuada L, Lorusso V, Lux G, Morisetti A, Morosini P, Serleti M, Uggeri FJJ: Conjugates of gadolinium complexes to bile acids as hepatocyte-directed contrast agents for magnetic resonance imaging. J Med Chem 2004, 47:3629.

22. Solaia BA, Terzic N, Pocsfalvi G, Gerena L, Tinant B, Opsenica D, Milhous WKJ: Mixed steroidal 1,2,4,5-tetraoxanes: antimalarial and antimycobacterial activity. Med Chem 2002, 45:3331.

23. Salunke DB, Hazra BG, Pore VS: Steroidal conjugates and their pharmacological applications. Curr Med Chem 2006, 13:813.

24. Carmo AML, Silva FMC, Machado PA, Fontes AP, Pavan FR, Leite CQ, Leite SR, Coimbra ES, Da Silva AD: Synthesis of 4-aminoquinoline analogues and their platinum(II) complexes as new antileishmanial and antitubercular agents. Biomed Pharmacother 2011, 65:204.

25. De Souza NB, Carmo AML, Lagatta DC, Alves MJM, Fontes APS, Coimbra ES, Da Silva AD, Abramo C: 4-aminoquinoline analogues and its platinum (II) complexes as antimalarial agents. Biomed Pharmacother 2011, 65:313.

26. Palomino JC, Martin A, Camacho M, Guerra H, Swings J, Portaela F: Resazurin microtiter assay plate: simple and inexpensive method for detection of drug resistance in Mycobacterium tuberculosis. Antimicrob Agents Chemother 2002, 46:2720.

27. Mossman T: Rapid colorimetric assay for cellular growth and survival: application to proliferation and cytotoxicity assays. J Immunol Meth 1983 , 65:55.

28. Musonda CC, Gut J, Rosenthal PJ, Yardley V, de Souza RCC, Chibale K: Application of multicomponent reactions to antimalarial drug discovery. Part 2. New antiplasmodial and antitrypanosomal 4-aminoquinoline gamma- and delta-lactams via a 'catch and release protocol. Bioorg Med Chem 2006, 14:5605.

29. Aher NG, Pore VS: Synthesis of Bile Acid Dimers Linked with 1,2,3Triazole Ring at C-3, C-11, and C-24 Positions. Synlett 2005, 14:2155.

30. Salunke DB, Hazra BG, Pore VS, Bhat MK, Nahar PB, Deshpande MV: New steroidal dimers with antifungal and antiproliferative activity. J Med Chem 2004, 47:1591.

31. Collins L, Franzblau SG: Microplate alamar blue assay versus BACTEC 460 system for high-throughput screening of compounds against Mycobacterium tuberculosis and Mycobacterium avium. Antimicrob Agents Chemother 1997, 41:1004.

32. Sereno D, Cordeiro da Silva A, Mathieu-Daude F, Ouassi A: Advances and perspectives in Leishmania cell based drug-screening procedures. Parasitol Int 2007, 56:3.

33. Vermeersch $M$, da Luz RI, Tote K, Timmermans JP, Cos P, Maes L: In vitro susceptibilities of Leishmania donovani promastigote and amastigote stages to antileishmanial reference drugs: practical relevance of stagespecific differences. Antimicrob Agents Chemother 2009, 53:3855.

34. Tempone AG, Martins de Oliveira C, Berlinck RG: Current approaches to discover marine antileishmanial natural products. Planta Med 2011, 77:572.

doi:10.1186/2191-2858-2-16

Cite this article as: Antinarelli et al: Increase of leishmanicidal and tubercular activities using steroids linked to aminoquinoline. Organic and Medicinal Chemistry Letters 2012 2:16.

\section{Submit your manuscript to a SpringerOpen ${ }^{\odot}$ journal and benefit from:}

- Convenient online submission

- Rigorous peer review

- Immediate publication on acceptance

- Open access: articles freely available online

- High visibility within the field

- Retaining the copyright to your article

Submit your next manuscript at $>$ springeropen.com 